\title{
Church Choir Online Communication and Music Recording and Streaming System
}

\author{
Egbono F. \\ Department of Computer Science \\ University of Port Harcourt \\ Port Harcourt, Nigeria
}

\author{
Ndigwe C. F. \\ Department of Computer Science \\ Chukwuemeka Odumegwu Ojukwu University \\ Uli, Nigeria
}

\begin{abstract}
Communication among choristers has left some choristers in the dark because of the present method used which has led to poor performance in ministration. In the light of this situation, a user friendly system with data storage abilities to facilitate an integrated and centralized system in the storage, management and presentation of data, recording and streaming music as well as in sending notification in the form of text messages and email messages is proposed in this paper. The methodology adopted in this work is Object Oriented Analysis and Design methodology (OOADM). The system was implemented using Microsoft C\# programming language which runs on Microsoft Visual Studio 2012 IDE and Microsoft SQL Management Server Studio 2012. This result show that the system handles the messaging and recording of the church choir music well as a solution for the communication problem.
\end{abstract}

Keywords: Music streaming; Choir Online communication; messaging system

\section{INTRODUCTION}

Technology have been growing continuously in many aspects of human life, one of them is in the religious practice. For the last few years, the adoption of information technology for communication in church is also growing. More and more people all around the world are turning to the internet and social media to find personal, social, and also religious information. Many churches are also having church websites and media departments that manage the activities going on in the internet. The Ecclesiastical institution is devoting more and more resources to improve their presence on the web (Bolu, 2012)

There are several studies how information and technology influence the church nowadays. Gunton (2011) in his research presented the important of information by developing an understanding how the church uses information in learning and the result showed that the exploration may help church organization, church leaders and lay people to consider how information can be used to grow faith, develop relationship, manage the church and respond the religious knowledge

More research came from (Bolu, 2012); he discussed the adoption of information and communication technology in church communication for growth in Nigeria. He analyze the perception of church leaders on internet usage for church growth, communication, as well as the deployment of church ICT infrastructure for church administration and human capital management. The result showed that most churches have email address and website but there is little communication between members and church leaders. In addition, not many churches upload bible studies, music, and other information on their website for people to download.
Finally although while most churches do not have ICT personnel and infrastructure well, they totally agree that they need to have one.

On the other hand, Seller said that information technology is very important for church. In his Journal entitled Technology and Ministry, Seller said that "Technology is a major issue for every church, because it is a major issue in society" (Seller, 2007). Seller also describe that website technology is meant to function as a form of community for congregation, it have a way for people to interact online, to connect with the church and with others in the congregation, and to stay connected when they are away, and also update users on what's happening within the church.

Grinter, (2011) presented the results of their research in four sections focused on different aspects of ministry served by ICTs: Corporate work; Sunday Worship Service; Coordinating the Church Community; and Outreach to People outside the Congregation. Further, Grinter also describe that technologies play an important role in the management of the church to support financial data, payroll for any employees, service for community and so forth. Further study come from (ZECH, 2013) in his research, he tried to find out the effective design of church website. Technology is a mainstay in most people lives especially for religious purpose, using website the church can provide information and keep members engaged with the church community. 


\section{ELECTRONIC COMMUNICATION SYSTEM}

An electronic communication system for use in church and other collaborative environments would ideally include a suite of capabilities that facilitate decision making and communication by two or more individuals. Such capabilities could include:

1. enabling users to view the history of multiple conversations with multiple parties (referred to hereinafter as "conversation history");

2. enabling users to view messages as soon as they are available without requiring the users to $\log$ onto a public bulletin board system (BBS) (referred to hereinafter as "instant access");

3. enabling users to view the content of messages without requiring that the messages first be selected (referred to hereinafter as "open display");

4. enabling users to conduct their conversations in privacy so that each user is the only person who can view the history and content of their respective multiple conversations (referred to hereinafter as "private conversations");

5. enabling users to undeniably agree to proposals made in the course of a conversation in such a way that the conversation is concluded (referred to hereinafter as "agreement"); and

6. Enabling users to participate in moderated conferences or informal chats, as well as in conversations (referred to hereinafter as "integrated modes").

\subsection{Church and Web Communication}

In 2007 the center for congregations offered grants to provide churches with computers, and their financial officer, and they noted that emerging web based systems would allow congregations to think in new ways about how they connect with and use information about people (Armstrong 2007). According to Capterra in its article on buyers guide for Church Management Software it is said that most Church Management Software has the ability to; keep track of contributions, memberships, and attendance. Manage schedules for events, classes, and worship services. Handle accounting needs, fund management, and ability to track income and expenses. Manage donations and online giving and offering collection. It can also be used in managing groups, ministries, and volunteers in church activities.

In its blog report on "top 7 free open source church management software solutions by Leah Readings", it can be said that most church management software were solely built with the aim of developing a database system that has the ability to help the church manage and track its members, visitors and sending of bulk emails and text messages to its members and visitors. (LEAH 2014).

Mithras, (2002) Prior art electronic systems, which include electronic mail (e-mail), bulletin board systems (BBS), instant messaging and chat rooms, offer some but not all of these capabilities and, as a result, are less than ideally suited to enterprise communications. The capabilities of these various communication systems can be modified for even more general use in other church related system.

The capabilities of the various communication systems are listed in table 1 below. The table also show the various features that can be easily seen on the various columns of the system and the various responses illustrating the availability of certain features in the system.

Table1: Capabilities of various communication systems

\begin{tabular}{|l|l|l|l|l|l|l|}
\hline System & Conv & $\begin{array}{l}\text { Instant } \\
\text { Access }\end{array}$ & $\begin{array}{l}\text { Open } \\
\text { Display }\end{array}$ & $\begin{array}{l}\text { Private } \\
\text { Conv }\end{array}$ & $\begin{array}{l}\text { Agreem } \\
\text { ent }\end{array}$ & $\begin{array}{l}\text { Integra } \\
\text { ted } \\
\text { Modes }\end{array}$ \\
\hline E-mail & No & Yes & No & Yes & No & No \\
\hline BBS & Yes & No & No & No & No & No \\
\hline $\begin{array}{l}\text { Instant } \\
\text { Messa } \\
\text { ging }\end{array}$ & No & Yes & Yes & Yes & No & No \\
\hline Chat & No & Yes & Yes & No & No & No \\
\hline
\end{tabular}

\section{ANALYSIS AND DESIGN}

System analysis is the decomposition of the system requirements into units that can form building blocks for the new system. In the review of the church electronic communication system it is clear that the Choir have no place in the system that is already existing. The paper presents a web communication system that captures the choir in the provision of communication within the church.

\subsection{Design}

Design is the synthesis of the system component parts that are required in the building of the new system. The system main users are the registered choir members the other registered church members and guests in the site. In figure 1, the actors are capable of carrying out certain activities such as communicating with the church site via bulletin boards or email systems and databases that are in the site. Church music and hymn are also prepared and stored in the databases for easy download by members and other users as well as by choir members themselves.

Users can then :

1. View Related Choir Activities

2. Download Music Files 
International Journal of Computer Applications Technology and Research

Volume 6-Issue 5, 234-241, 2017, ISSN:-2319-8656

Fig 1. Choir Record and Messaging Use Case Model Diagram 


\subsection{Information and Product Flow Diagram}

The diagram in figure 1 shows a use case diagram that describes the functionalities of the different factors in relation to the different use cases.

The USE CASE MODEL is made up of three actors;
1. Registered Choir User
2. Registered Choir Member
3. Web User

These actors serve as the clients that will use the proposed system.

The various Cases in the Model include;
3. Manage Choir Members
4. Manage Choir Users
5. Manage Choir Patrons/Matrons
6. Manage Choir Events
7. Send Email(s)
8. Send SMS Messages(s)
9. View Related Choir Activities
10. Download Music Files

Based on the implementation of a web based software application for the new system, the following are the limitations associated with the new system;

1. Lack of internet enabled platform will deprive users from operating the system.

2. Outdated web browsers will restrict the functionalities attached to the new system

3. Slow operation of the internet will affect the flow of operation of the new system.

4. Lack of power supply affects the operation of the new system.

\subsection{High level Model of the Proposed}

\section{System}

The proposed system is built with a high level model class library called SignalR which is a technology developed by Microsoft technology in the year 2014 .

SignalR is a new library for ASP.Net developers that make developing real-time web functionality easy. SignalR allows bi-directional communication between server and client. Servers can now push content to connected clients instantly as it becomes available, rather than having the server wait for a client to request new data.

SignalR can be used to add any sort of "real-time" web functionality to your ASP.Net application. While chat is often used as an example, you can do a whole lot more. Any time a user refreshes a web page to see new data, or the page implements a long polling to retrieve new data, it is a candidate for using SignalR. Examples include dashboards and monitoring applications, collaborative applications (such as simultaneous editing of documents), job progress updates, and real time forms. SignalR provides a simple API for creating server to client remote procedure calls (RPC) that call JavaScript functions in client browsers (and other client platforms) from server-side .Net Code.

In figure 2 the server invocation of client methods is clearly illustrated using the MyClientFunc( ), a function executing on the client . The client application execute and call for action on the server using its Javascripts and the server application on the .NET responses by processing the action required.

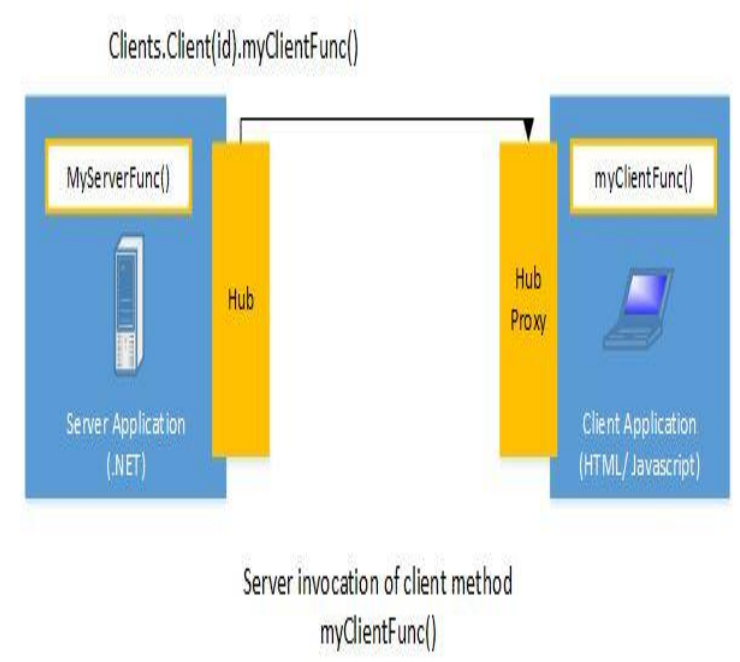

Fig 2: Server to Client Method

In the corresponding figure 3 instead of using a client function a server function is used in offering the response. When MyServerFunc() is called the request made by the client function is been processed in the server machine and response gets back to the requesting

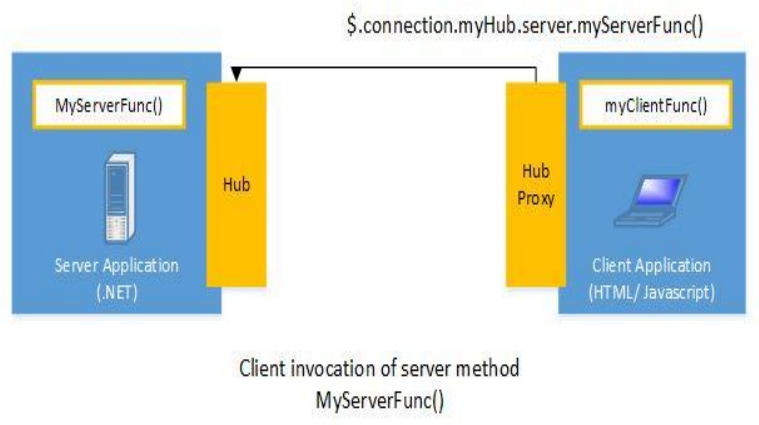

Fig 3: Client to Server Method

SignalR handles connection management automatically, and lets broadcast messages to all connected clients simultaneously, like a chat room. You can also send messages to specific clients. The connection between the client and server is persistent, unlike a classic HTTP connection, which is re-established for each communication. (Fletcher2014) 


\section{IMPLEMENTATION}

Using the design presented for the church choir system, the implementation of the design was also carried out and presented. The user interface of the implemented system is discussed in the documentation carried out during the testing of the system. The explanation of the implemented system functionality was also clearly illustrated in the development process. The system interface was developed using HTML and the client internal functionality facilitated using Java script. The server side runs a windows server that have .NET fully installed and functional.

\subsection{Software Testing}

The following a test scenarios to be implemented in the application of the new system

\subsubsection{Login}

The Login Page is made up of two Login Modes which are USER and MEMBER Mode.

\section{USER MODE:}

Enter Username: UserTest (CAPS or No CAPS)

Enter Password: UserTest (CAPS or No CAPS)

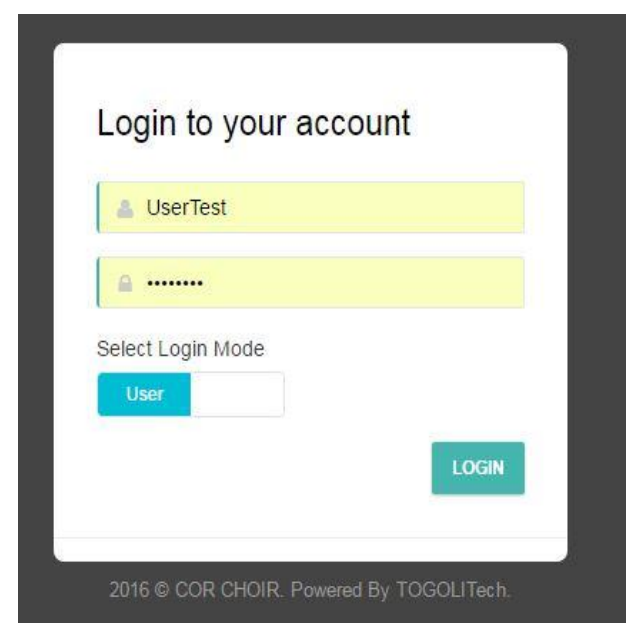

Fig 4: Login Mode

\subsubsection{Member Page}

The member page is used by the users to create new member registration where a new member can provide data that will be captured and automatically be added to the database provided by the system.

Once Add new member button is activated the corresponding page shows up in the system awaiting response from the users who are expected to fill in the data for the system to use in processing various operations. The new member window is shown in figure 5 .

Add New Member: To add a new Member, click the Add new button located on the Loaded Datatable , a Pop-Up Modal Form shows, there fill in Data into all fields in the form and then submit the form for the server to process.

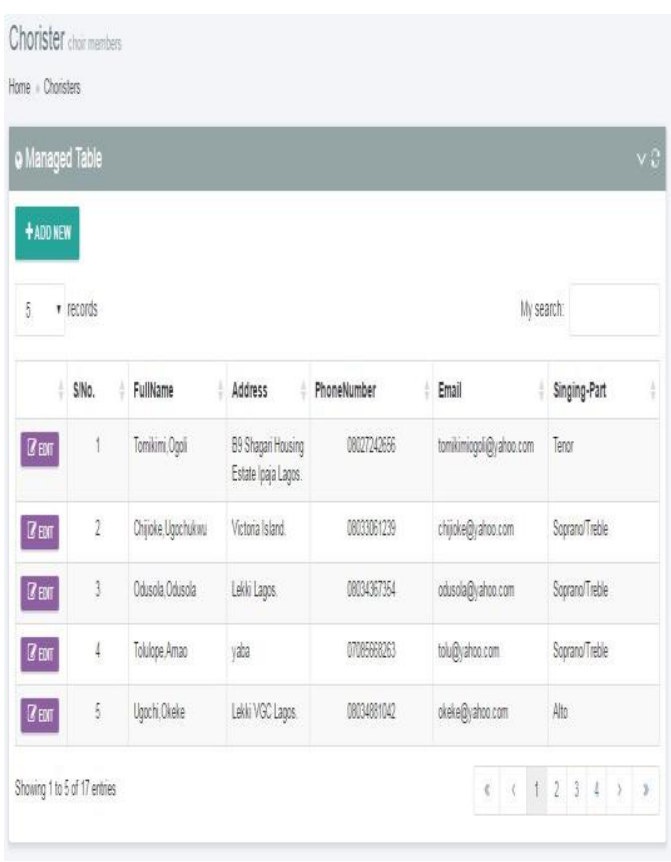

Fig 5: Member Output Form

If a user information are incomplete or improperly presented, the user can be allowed to update the content of the information provided. This action is provided for in the setup and configuration window provided in the system. This is illustrated in figure 6 . The critical information are displayed for the user to make some adjustment on the information already provided. Based on the information provided the users information can be easily updated using the window.

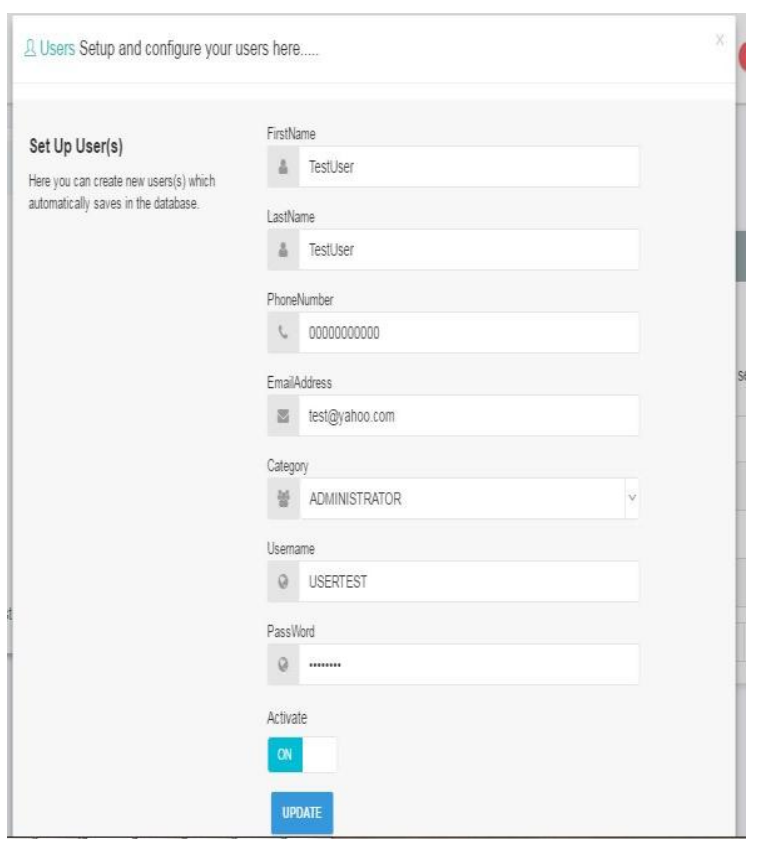

Fig 6: User Setup and Configure Form 


\subsection{Compose Email Page}

An internal mailing system is used by the choir members in sharing information concerning their activities in the church.

The mailing system contain email setup window used to compose the message before it can be sent. Sending of the email message is done after composing it as shown in figure 7.

Send Email Message : To send a new Email, fill in the fields in the Compose TAB section of the form and click send.

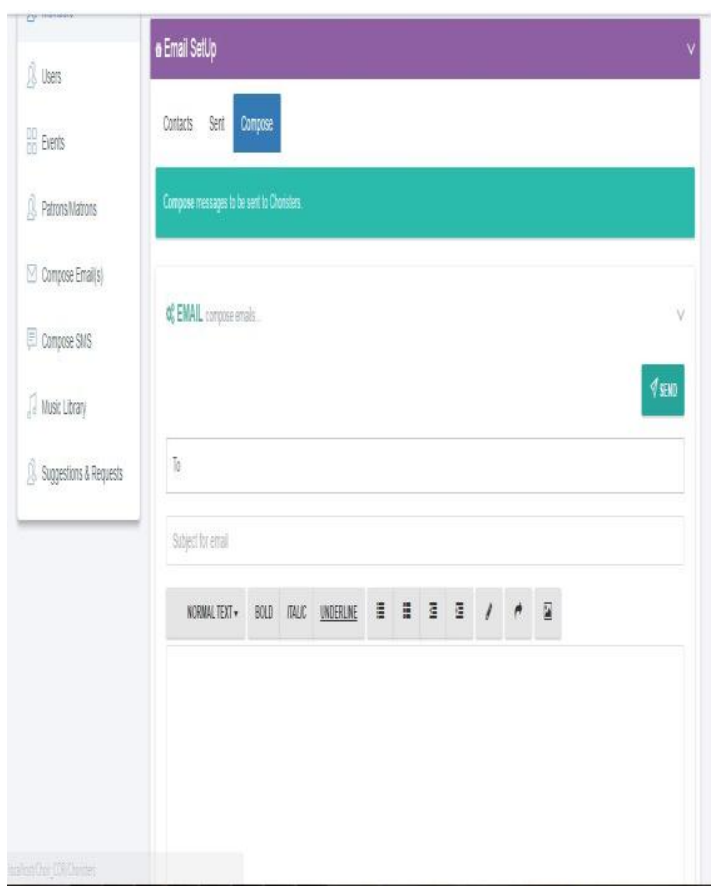

Fig 7: Send Email Message Form

\subsection{Music Library Page}

The system provides for music available as database that can be played by members by downloading them from the site. But before the music will be downloaded it has to be uploaded into the site by the system admin after it must have being made available by the choir. The buttons are provided for the user to add new music files once they are ready for upload and the page for streaming the music directly from the site is also provided to make sure that users can enjoy church music directly from the site.

Add New Music file: To add a new Music File, click the Add new button located on the Loaded Data table , a Pop-Up Modal Form shows, then fill in Data into all fields in the form and ensure that you upload a music file before saving unless the operation is unsuccessful. Once a music is uploaded the copy of the music is saved on the system for download.

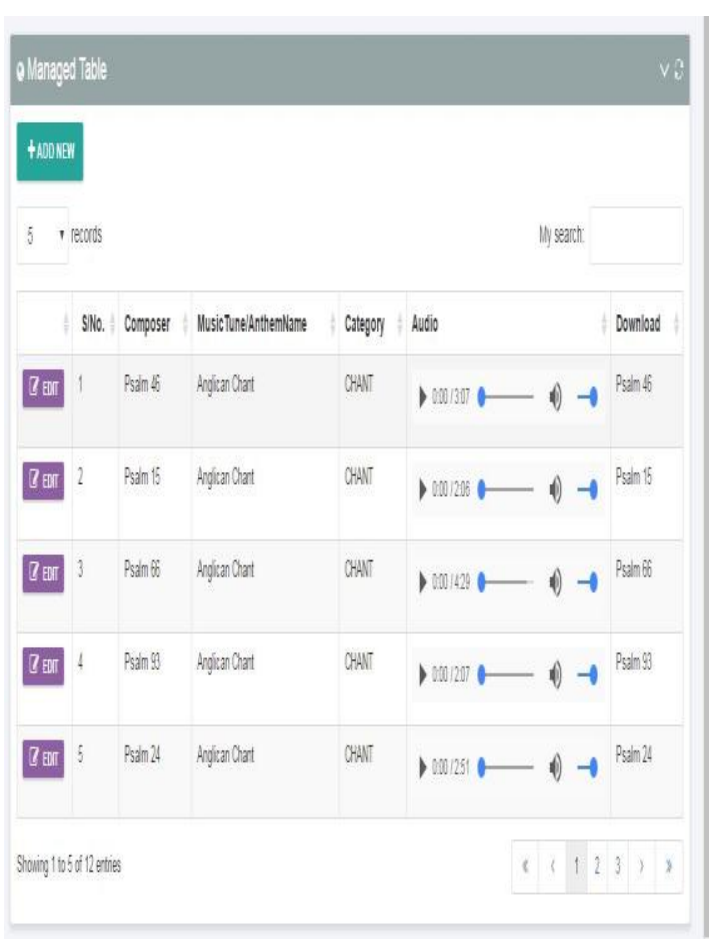

Fig 8: Music Library Output Form

In figure 8 the music library output form show the audio play back button from where a church member or other users can stream the music and play it directly from the site. The button that can be used to download the music is also provided in the system so that the file can be directly downloaded into users systems and then played back from the users machine.

\section{RESULTS AND FINDINGS}

When the site was tested using real life data from a selected church the web application functioned the way it was expected to perform. Operations such as getting of values from the users, setting of values for the users and fetching of values for the users and other operations are executed based on the functionality required by the page or form.

The music library menu provides a platform where different hymns, chants and anthems are uploaded into the database, also a table that shows a list of uploaded music files are presented to the user along with the option to listen to what has been uploaded from the page. The system was developed with the main purpose of providing a messaging platform and making music available to members of the church through the download platform of the software application, this project has been able to meet the goals of this project by providing a user friendly system that enables communication through text and email messaging easy. Through its music library, Hymns, Chants and Anthems from great composers are also made available to the listening pleasure of the church.

The new technology SignalR used in developing the system provides in establishing a real-time web functioning system which reduces the time it takes for the system to retrieve new data. 


\section{CONCLUSIONS}

Within the timeframe of the project discoveries found out has shown that the file structure system of keeping records in church is still in use and transmission to electronic system need to be carried out gradually. The file structure may not be eliminated immediately but should serve as an area to fall back to in case of unforeseen instances that can occur to the software application developed during transition.

In this paper a system for the choir to use in communication within their group and with the church have been developed and proposed for the use of the church. Looking at the need of todays church it is clear that, a Web base software application along with a well-defined database system is needed to help provide a process that will bridge the break in communication between members and this paper have proposed a solution.

\section{RECOMMENDATION}

In the light of the research we recommend the system for the Church to be used by the Choir as it will enhance the performance and ministration of the choir. The system will assist them in carrying out their duties with greater efficiency.

It will also expand their kill in electronic communication and make their music available for a larger audience to listen to by using the music download facility provided on the system.

Developers of similar church system can also leverage on the system and expand on the features provided in the system.

\section{ACKNOWLEDGMENTS}

We acknowledge the students who collected the church data used in test running the system and the Church that provided the environment for direct test using the real life circumstances.

\section{REFERENCES}

Alexander, Michael, and John Walkenbach.(2010) Excel Dashboards and Reports. Indianapolis: Wiley Incorporation.

"Automated Text messages." PhoneTree. n.d. https://www.phonetree.com/features/automatedtext-message/ (accessed October 20, 2016).

Bolu, C A. "The Church in the Contemporary World: Information and Communication Technology in Church Communication for Growth: A Case Study." Journal of Media and Communication Studies, vol. 4,, 2012: 80-94.

"Churches Phone Messaging and Calling." PhoneTree. n.d. https://www.phonetree.com/industries/churchesorganizations/ (accessed October 20, 2016).

"Dashboard Business." Wikipedia. October 19, 2016. https://en.wikipedia.org/wiki/Dashboard_(business) (accessed October 24, 2016).

Decelles-Zwerneman, Julia. Capterra. July 1, 2016. http://www.Capterra.com (accessed July 23, 2106).
Dye, T. Chms selection process. 052011. http://tonydye.typepad.com (accessed July 23, 2016).

Fletcher, Patrick. "Introduction to SignalR." 2014.

Grinter, R E. "Technology in Protestant Ministry." Computer Supported Cooperative Work, 2011.

Gunton, L. "Religious Information Literacy: Using Information to Learn in Church Community." Australian Library Journal, vol. 60, 2011: 155-164.

Harvey, C F. "Technology and the Church Through the Centuries,Annual Conference Association of Nazarene Sociologist and Researchers Heritage Center." 2006.

Leah, Merrill. "The Smart Guide to Buying Church Management Software." 2014.

Margaret, Rouse. SearchSOA. n.d. http://searchsoa.techtarget.com/definition/objectoriented-programming (accessed July 23, 2016).

Mithras, Maurille C. Internet messaging system and method for use in computer networks. USA Patent US 6484196 B1. November 19, 2002.

O'Docherty, M.(2005) Object-Oriented Analysis and Design: Understanding System Development with UML 2.0. Indianapolis: John Wiley \& Sons Ltd.

Pouncey, Ian, and Richard York.(2011) Beginning CSS Cascading Style Sheet for Web Design 3rd Edition. Indianapolis: Wiley Publishing Incorporated.

Sellers, R. "Technology and Ministry Current Trends." The Clergy Journal, 2007.

Spaanjaars, Imar.(2014) Beginning ASP.NET 4.5.1 in C\# and VB.NET. Indianapolis: John Wiley \& Sons Incorporated.

Vangie, Beal. WeboPedia. n.d. http://webopedia.com/TERM/A/API.html (accessed july 23, 2016).

Vieira, Robert.(2009) Beginning Microsoft SQL Server 2008 Programming. Indianapolis: Wiley Publishing Incorporated.

Watson, Karli, Jacob Vibe Hammer, John D Reid, Morgan Skinner, Daniel Kemper, and Christian Nagel.(2013) Beginning Visual C\# 2012 Programming. Indianapolis: John Wiley \& Sons Incorporated.

"What is Cloud base technology." littlehotelier. n.d. http://www.littlehotelier.com/what-is-cloud-basedtechnology/ (accessed October 20, 2016).

Wilton, Paul, and Jeremy McPeak.(2010) Beginning Javascript 4th Edition. Indianapolis: Wiley Publishing Incorporated.

Zech, C, W Wagner, and R West. "The Effective Design of Church Web Sites : Extending the Consumer Evaluation of Web Sites to the Non Profit Sector." Information. Information System Management, vol. 30, 2013: 92-99. 


\section{ABOUT THE AUTHORS}

Dr. Fubara Egbono is a database researcher and computer hardware engineering expert. His research interest is in Information System Development and application of software in solving local problems and data management in the Niger Delta communities in Nigeria.

Chinwe Ndigwe is a Lecturer at Department of Computer Science, Chukwuemeka Odumegwu Ojukwu University, Uli, Anambra State. Her research interest is ICT application and Data Mining. 